\title{
Pelatihan dan Pengadaan Alat Tulis dan Media Pembelajaran di TK Al Fasha
}

\author{
Mariana Ulfah Hoesny ${ }^{*}$, , Aly Imron ${ }^{2}$, Lia Agustina ${ }^{3}$, Pritantina Yuni Lestari ${ }^{4}$, Ririn Pratiwi Suharto ${ }^{5}$ \\ 1,2 Jurusan Teknik Elektro, Politeknik Negeri Malang, \\ ${ }^{3}$ Jurusan Akuntansi, Politeknik Negeri Malang \\ ${ }^{4,5}$ Jurusan Administrasi Niaga, Politeknik Negeri Malang \\ e-mail: *,1 marianah.ulfah@polinema.ac.id
}

\begin{abstract}
Abstrak
Pendidikan inklusi telah menjadi kebutuhan karena bermunculannya berbagai kasus Anak Berkebutuhan Khusus (ABK) yang semakin banyak. Tetapi, masih belum banyak sekolah dan lembaga pendidikan lainnya yang menyediakan pendidikan inklusi khususnya bagi ABK. Pada intinya, pendidikan ini belum populer di Indonesia. Berdasarkan hal tersebut, maka diselenggarakan kegiatan pengabdian pada masyarakat berbentuk pelatihan dan perbaikan fasilitas yaitu melalui pengadaan alat tulis dan media pembelajaran bagi ABK di TK Inklusi Al Fasha. Sebanyak 15 orang guru dari berbagai latar belakang pendidikan mengikuti pelatihan serta penyerahan alat tulis dan media pembelajaran secara simbolik. Kegiatan pelatihan difokuskan pada penggunaan mainan edukatif sebagai salah satu media pembelajaran bagi ABK. Para guru diberikan wawasan tentang bagaimana menggunakan mainan edukatif secara kreatif sesuai dengan tingkat usia dan kebutuhan anak berkebutuhan khusus. Kegiatan pengabdian pada masyarakat ini berjalan dengan lancar yang dapat disimpulkan dari tingkat kehadiran guru yang mengikuti pelatihan serta tingkat keterserapan materi yang diberikan.
\end{abstract}

Kata kunci : pendidikan inklusi, ABK, usia dini, media belajar

\section{PENDAHULUAN}

Pendidikan merupakan salah satu faktor penentu kemajuan suatu bangsa dan negara. Dengan alasan ini, pendidikan yang maju dan berkualitas baik sangat penting peranannya dalam pembangunan dan kemajuan. Telah banyak negara yang sistem pendidikannya sangat baik dan mendukung kemajuan negara tersebut, Seperti misalnya Finlandia, Jepang, Amerika Serikat dan Australia.

Merujuk pada hal tersebut, pendidikan bagi sebuah negara memegang peranan yang sangat penting. Khususnya untuk mencetak sumber daya manusia yang berkualitas sehingga mendorong kemajuan dan perubahan. Saat ini pendidikan di Indonesia dihadapkan dengan berbagai permasalahan yang tidak mudah dipecahkan, Sehingga turut berpengaruh pada pembangunan dan kemajuan. Beberapa permasalahan tersebut misalnya kualitas guru, penyediaan sarana dan prasarana termasuk bangunan gedung, perpustakaan dan media pembelajaran. Berbagai usaha telah dilakukan oleh pemerintah untuk memperbaiki kualitas pendidikan. Selain itu masyarakat juga melakukan berbagai upaya untuk membantu mencari solusi dari berbagai permasalahan tersebut. Kegiatan PPM ini merupakan salah satu upaya untuk mencari jalan keluar permasalahan khususnya pengadaan media pembelajaran dan peningkatan kualitas PBM melalui pelatihan guru.

Salah satu yang di deklarasikan pada Deklarasi Bangkok tahun 1991 adalah hak mendapatkan pendidikan bagi semua (education for all). Hal ini menjadi cerminan pentingnya pendidikan bagi semua warga negara dunia. Warga negara Indonesia sebagai bagian dari warga negara dunia memiliki hak yang sama untuk mendapatkan pendidikan. Warga negara Indonesia memiliki hak, harkat, derajat dan martabat yang sama untuk memperoleh pendidikan yang akan membantu perbaikan kesejahteraan. Sebagai warga negara, ABK (anak berkebutuhan khusus) juga berhak atas pendidikan yang layak. ABK tidak dimarjinalkan dalam hal ini karena pendidikan berperan penting dalam peningkatan kualitas hidup mereka.

Dengan dasar ini pendidikan bagi ABK yang dikenal dengan pendidikan inklusi bermunculan di Indonesia. Sekolah inklusi yang berbeda dengan 
sekolah reguler dan berbeda pula dengan Sekolah Luar Biasa (SLB) menjelma dengan pola tersendiri dengan model pembelajaran yang inklusif bagi semua peserta didik. Sekolah inklusi bukan sekedar euforia perwujudan hak asasi manusia, tetapi sudah menjadi komoditas kebutuhan setiap manusia terutama yang menyandang predikat ABK. Sekolah reguler dengan orientasi inklusif merupakan cara yang efektif untuk memerangi diskriminasi, menciptakan masyarakat terbuka, membangun suatu masyarakat yang inklusif, dan mencapai pendidikan untuk semua. Lebih dari itu sekolah inklusi memberikan pendidikan yang efektif kepada mayoritas peserta didik untuk meningkatkan efisiensi sehingga menekan biaya untuk keseluruhan sistem pendidikan [1].

Pendidikan inklusif adalah sistem layanan pendidikan yang mensyaratkan anak berkebutuhan khusus belajar di sekolah-sekolah terdekat di kelas biasa bersama teman-teman seusianya [2]. Dengan demikian dapat disimpulkan bahwa penyelenggaraan pendidikan inklusi menuntut sekolah yang menampung semuaa murid di kelas yang sama. Program pendidikan yang disediakan merupakan program yang layak dan mendukung tercapainya tujuan pendidikan untuk mewujudkan sumber daya manusia yang berkualitas. Tetapi program tersebut disesuaikan dengan kemampuan dan kebutuhan setiap murid dengan bantuan dan dukungan guru.Semangat penyelenggaraan pendidikan inklusif adalah memberikan kesempatan atau akses yang seluas-luasnya kepada semua anak untuk memperoleh pendidikan yang bermutu dan sesuai dengan kebutuhan individu peserta.

Secara umum pendidikan adalah usaha sadar dan terencana untuk mewujudkan suasana belajar dan proses pembelajaran agar peserta didik secara aktif mengembangkan potensi pribadinya untuk memiliki kekuatan spiritual keagamaan, pengendalian diri, kepribadian, kecerdasan, akhlak mulia dan keterampilan yang diperlukan dirinya, masyarakat, bangsa dan Negara [3]. Oleh sebab itu inti dari pendidikan inklusi adalah hak azasi manusia atas pendidikan. Suatu konsekuensi logis dari hak ini adalah semua anak mempunyai hak untuk menerima pendidikan yang tidak mendiskriminasikan dengan kecacatan, etnis, agama, bahasa, jenis kelamin, kemampuan dan lain-lain. Tujuan praktis yang ingin dicapai dalam pendidikan inklusi meliputi tujuan langsung oleh anak, oleh guru, oleh orang tua dan oleh masyarakat.

Inklusi berasal dari kata inclusion yang berarti penyatuan. Inklusi mendeskripsikan sesuatu yang positif dalam usaha-usaha menyatukan anak- anak yang memiliki hambatan dengan cara-cara yang realistis dan komprehensif dalam kehidupan pendidikan yang menyeluruh [4]. Pendidikan inklusi didefinisikan sebagai sistem layanan pendidikan luar biasa yang mempersyaratkan agar semua anak luar biasa dilayani di sekolah-sekolah terdekat di kelas biasa bersama. Pelayanan inklusi merupakan layanan pendidikan. Pendekatan inklusi merupakan layanan pendidikan yang disesuaikan dengan kebutuhan-kebutuhan khusus anak secara individual dan pembersamaan klasikal.

Sekolah inklusi adalah sekolah yang menampung semua murid di kelas yang sama. Sekolah ini menyediakan program pendidikan yang layak, menantang, tetapi sesuai dengan kemampuan dan kebutuhan semua murid maupun bantuan dan dukungan yang dapat diberikan oleh para guru agar anak-anak berhasil [5].

Proses menuju pendidikan inklusi bagi Anak Berkebutuhan Khusus (ABK) di Indonesia hakikatnya sudah berlangsung lama, yakni sejak tahun 1960 an ditandai dengan berhasil diterimanya beberapa lulusan SLB Tunanetra di Bandung untuk masuk ke sekolah umum meskipun ada unsur penolakan dari sekolah. Hal ini perlahan mengubah pandangan masyarakat umum terhadap penyandang disabilitas. Ditandai dengan mulai diterimanya penyandang cacat di sekolah umum [6].

Pada sekolah inklusi setiap anak sesuai dengan kebutuhan khususnya, diusahakan dapat dilayani secara optimal dengan melakukan berbagai modifikasi dan atau penyesuaian mulai dari kurikulum, sarana-prasarana, tenaga pendidik dan kependidikan, sistem pembelajaran sampai pada sistem penilaian. Keuntungan dari pendidikan inklusi adalah bahwa anak penyandang disabilitas dan anak biasa dapat saling berinteraksi secara wajar sesuai dengan tuntutan kehidupan sehari-hari di masyarakat dan kebutuhan pendidikannya dapat terpenuhi sesuai dengan potensinya masing-masing.

Pendidikan inklusi mensyaratkan pihak sekolah yang harus menyesuaikan dengan tuntutan kebutuhan individu peserta didik, bukan peserta didik yang menyesuaikan dengan sistem persekolahan. Pandangan mengenai pendidikan yang harus menyesuaikan dengan kondisi peserta didik ini sangat terkait dengan adanya perbedaan yang terdapat dalam diri peserta didik. Pandangan lama yang menyatakan bahwa peserta didiklah yang harus menyesuaikan dengan pendidikan dan proses pembelajaran di kelas lambat laun berubah. 
Bentuk penyelenggaraan pendidikan bagi anak berkebutuhan khusus ada berbagai pilihan, yaitu [7]:

1. Reguler Class Only (Kelas biasa dengan guru biasa)

2. Reguler Class with Consultation (Kelas biasa dengan konsultan guru PLB)

3. Itinerant Teacher (Kelas biasa dengan guru kunjung)

4. Resource Teacher (Guru sumber, yaitu kelas biasa dengan guru biasa, namun dalam beberapa kesempatan anak berada di ruang sumber dengan guru sumber)

5. Pusat Diagnostik-Prescriptif

6. Hospital or Homebound Instruction (Pendidikan di rumah atau di rumah sakit, yakni kondisi anak yang memungkinkan belum masuk ke sekolah biasa).

7. Self-contained Class (Kelas khusus di sekolah biasa bersama guru PLB)

8. Special Day School (Sekolah luar biasa tanpa asrama)

9. Residential School (Sekolah luar biasa berasrama)

TK Inklusi Al Fasha adalah sebuah lembaga pendidikan swasta yang terletak di Kepanjen, Kabupaten Malang. Saat ini sekolah tersebut memiliki sekitar 20-25 siswa yang seluruhnya adalah ABK dengan berbagai kelainan seperti speech delay, disleksia, autisme dan attention deficit. Terdapat tenaga pengajar yang berjumlah 10 orang dengan latar belakang pendidikan beraneka ragam. Ruang kelas yang dimiliki sekitar 8 ruang, dengan 1 ruang kelas berukuran kecil yang ditempati oleh 1 orang guru dan 2 orang siswa ABK. Fasilitas bangunan gedung sudah cukup memadai walaupun masih diperlukan perbaikan. Sedangkan untuk media pembelajaran masih cukup minim jumlahnya. Demikian juga dengan stok alat tulis. Alat tulis yang dibutuhkan di sekolah ini berbeda dengan alat tulis di sekolah pada umumnya karena alat tulis tersebut dibuat khusus untuk siswa ABK. Alat tulis untuk siswa ABK umumnya memiliki beberapa kriteria seperti menggunakan bahan yang aman karena siswa ABK kemungkinan besar memiliki reaksi alergi terhadap zat tertentu. Sebagai contoh, diperlukan kertas serta pensil yang aman digunakan pada saat dilakukan terapi [8]. Hal ini mendukung perlunya penyediaan alat tulis khusus bagi ABK di TK Al Fasha.

Terkait dengan permasalahan dan kondisi nyata yang telah dipaparkan, maka kegiatan pengabdian pada masyarakat ini diselenggarakan dengan tujuan sebagai berikut:

a. Memberikan pelatihan kepada para guru pengajar di TK/PAUD Al Fasha tentang mentode pembelajaran bagi ABK.

b. Meningkatkan fasilitas yang tersedia di TK/PAUD Al Fasha untuk mendukung pembelajaran yang lebih berkualitas.

c. Menjalin hubungan yang baik antara masyarakat atau lembaga pendukung dengan Politeknik Negeri Malang.

\section{METODE}

\subsection{Metode Pelaksanaan}

1. Ceramah

Pada sesi ceramah disampaikan metode pembelajaran yang tepat bagi anak berkebutuhan khusus. Metode yang umumnya digunakan pada pembelajaran ABK yaitu komunikasi, analisis tugas dan pembelajaran kooperatif. Metode komunikasi dan analisis tugas ini sangat penting dalam pelaksanaan pembelajaran $\mathrm{ABK}$, karena dalam proses pembelajaran diperlukan komunikasi yang baik antara guru dengan pembelajar. Sedangkan analisis tugas sebaiknya dilakukan untuk memeriksa langsung pengerjaan tugas yang diberikan oleh guru. Pembelajaran kooperatif diterapkan karena metode ini efektif untuk menciptakan suasana pembelajaran yang menyenangkan. Hal tersebut sangat penting untuk dihadirkan di dalam kelas dengan siswa ABK.

\section{Diskusi dan Tanya Jawab}

Setelah penyajian materi dilakukan, terdapat sesi diskusi dan tanya jawab. Sesi ini diberikan untuk menciptakan interaksi antara guru sasaran PPM dengan tim PPM yang menyajikan materi. Sehingga guru dapat bertanya dan berdiskusi terkait hal-hal yang belum dipahami dari materi yang telah disajikan.

\section{Demonstrasi Penggunaan Mainan Edukatif}

Selain penyajian materi tentang metode pembelajaran bagi ABK, kegiatan PPM ini juga memberikan bantuan berupa mainan edukatif sebagai media pembelajaran dan alat tulis bagi anak berkebutuhan khusus. Setelah penyampaian materi, dilakukan demonstrasi cara penggunaan media pembelajaran yang diberikan. Media pembelajaran yang diberikan antara lain puzzle berbahan kayu dengan berbagai bentuk seperti alphabet, huruf hijaiyyah dan alat transportasi. Selain itu juga 
diberikan buku tulis, buku gambar, krayon dan pensil warna.

\subsection{Rancangan Evaluasi}

Bagian ini menyajikan rancangan evaluasi baik sebelum maupun setelah pelaksanaan PPM.

\section{Evaluasi Sebelum Pelaksanaan Kegiatan}

Sebelum pelaksanaan kegiatan dilakukan observasi langsung. Tim PPM berkunjung ke TK/PAUD Inklusi Al Fasha yang berlokasi di Kepanjen, Kabupaten Malang. Dalam kegiatan ini tim PPM mencari informasi mengenai kondisi sekolah, seperti jumlah siswa, jumlah guru, fasilitas yang terdapat di sekolah, jam belajar yang berlaku, metode pembelajarana yang digunakan serta kebutuhan sekolah tersebut, baik berupa fisik maupun non fisik.

Dari kegiatan evaluasi ini didapatkan sejumlah informasi seperti jumlah kelas, yaitu 4 kelas yang terbagi ke dalam 2 kelas TK dan 2 kelas PAUD. Selain itu jam belajar dijadwal pagi dan siang, sehingga tidak terjadi kelebihan jumlah siswa selama proses pelaksanaan belajar mengajar. Terdapat 15 orang guru termasuk kepala sekolah. Latar pendidikan guru rata-rata adalah strata 1, dan selebihnya adalah Diploma III.

2. Evaluasi Selama Pelaksanaan Kegiatan

Selama pelaksanaan kegiatan terdapat beberapa hal yang dievaluasi seperti:

a. Evaluasi terhadap tingkat kehadiran peserta, kesiapan materi, serta fasilitas selama pelaksanaan.

b. Evaluasi terhadap hambatan baik dalam hal penyampaian materi, maupun dalam hal penyediaan media pembelajaran yang diberikan.

c. Evaluasi terhadap ketepatan materi dan media pembelajaran yang diberikan kepada sekolah.

d. Evaluasi terhadap pemahaman atau tingkat penyerapan peserta terhadap materi yang diberikan.

\section{Evaluasi Setelah Pelaksanaan Kegiatan}

Setelah kegiatan PPM ini dilaksanakan terdapat beberapa evaluasi yang berkaitan dengan materi yang disampaikan serta media pembelajaran yang diberikan. Materi yang diberikan perlu diperkuat lagi dengan menyediakan sesi latihan atau praktek sehingga penyerapan materi meningkat. Selain itu diperlukan media pembelajaran lain yang berupa mainan edukatif yang bermanfaat untuk melatih motorik halus dan kasar siswa sekolah tersebut.

\section{HASIL DAN PEMBAHASAN}

Kegiatan PPM ini berbentuk pelatihan dan penyediaan media pembelajaran dalam bentuk mainan edukatif serta alat tulis. Hal ini ditujukan untuk meningkatkan dan memperbaharui pengetahuan guru yang membina siswa ABK. Selain itu kegiatan ini bertujuan memperbaiki fasilitas yang tersedia di TK/PAUD Al Fasha.

Peserta kegiatan ini adalah para guru TK Inklusi Al Fasha serta siswa tingkat 2. Jumlah guru di TK ini adalah 15 orang yang berstatus sebagai guru tetap. Latar belakang pendidikan para guru sebagian besar adalah strata 1 dan selebihnya adalah diploma III. Para siswa tingkat 2 memiliki beragam kebutuhan khusus seperti tuna rungu, tuna wicara, autisme, hiperaktif, down syndrome, dyslexia, lambat bicara dan lambat belajar. Kegiatan ini juga dihadiri oleh Kepala sekolah TK Al Fasha yang sangat mendukung dan mengapresiasi keikutsertaan guru dan siswa.

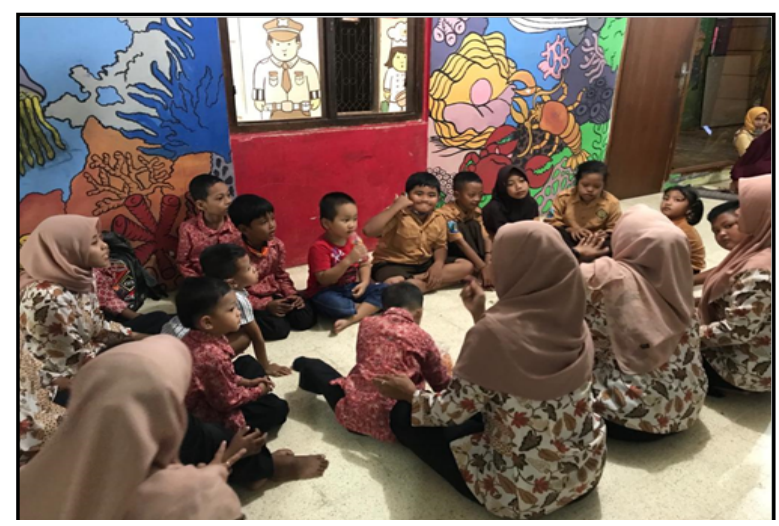

Gambar 1 Pelatihan bersama guru dan siswa

Pelaksanaan kegiatan ini menghasilkan beberapa hal sebagai berikut:

- Peningkatan pengetahuan para guru mengenai metode pembelajaran yang dapat digunakan untuk menangani $\mathrm{ABK}$.

- Pembaharuan pengetahuan terkait metode pembelajaran bagi ABK.

- Pembaharuan pengetahuan mengenai penggunaan mainan edukatif untuk siswa ABK.

- Peningkatan fasilitas media pembelajaran yang berbentuk mainan edukatif.

- Perbaikan fasilitas yang berupa alat tulis seperti buku tulis, buku gambar, krayon dan pensil warna bagi siswa ABK. 


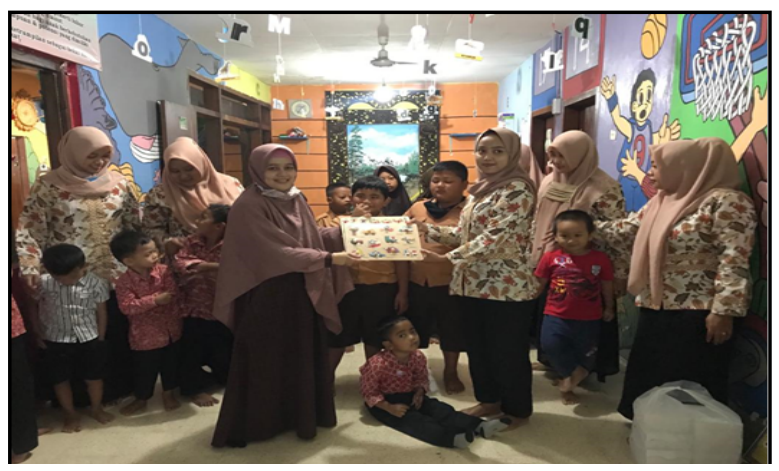

Gambar 2 Penyerahan mainan edukatif

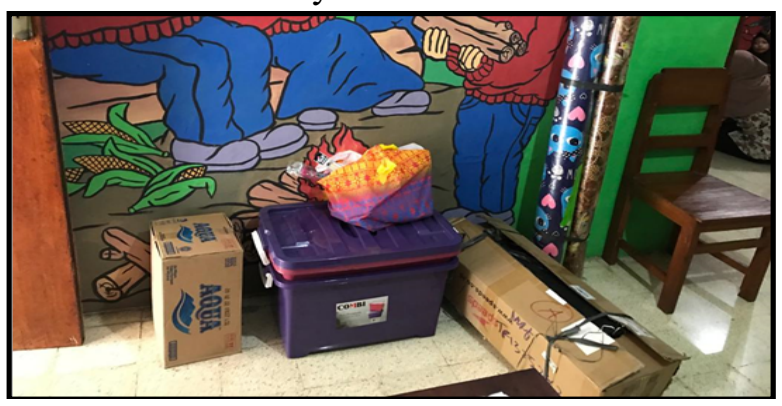

Gambar 3. Mainan edukatif dan alat tulis yang diserahkan untuk ABK

Dalam pelaksanaan kegiatan PPM ini terdapat beberapa kendala dalam pelaksanaannya. Salah satu kendala adalah tim PPM harus menyesuaikan antara dana yang tersedia dengan media pembelajaran yang dibutuhkan oleh sekolah. Menyelaraskan kebutuhan sekolah dengan dana PPM yang tersedia menjadi kendala tersendiri karena peralatan yang harus disediakan seperti mainan edukatif memerlukan biaya yang tidak sedikit. Hal ini menjadi kendala tersendiri bagi tim PPM.

Selain itu terdapat kendala dalam melakukan observasi awal. Hal ini disebabkan oleh terjadinya pandemi. Sekolah sasaran ditutup pada awal pandemi untuk menghindari terjadinya penyebaran wabah Corona. Tetapi, dengan komunikasi yang baik antara tim PPM dengan pihak sekolah observasi dapat dilakukan dan kegiatan dapat terlaksana dengan baik.

Tabel 1 daftar alat tulis dan mainan edukatif

\begin{tabular}{|c|c|c|}
\hline No & Nama Barang & Jumlah \\
\hline $\mathbf{1}$ & Puzzle huruf & 10 buah \\
\hline $\mathbf{2}$ & Puzzle huruf hijaiyah & 10 buah \\
\hline $\mathbf{3}$ & Puzzle alat transportasi & 5 buah \\
\hline $\mathbf{4}$ & Puzzle buah-buahan & 5 buah \\
\hline $\mathbf{5}$ & Puzzle 'rumah' & $5 \mathrm{set}$ \\
\hline $\mathbf{6}$ & Puzzle 'kapal' & $5 \mathrm{set}$ \\
\hline $\mathbf{7}$ & Media Belajar Jam & $2 \mathrm{set}$ \\
\hline $\mathbf{8}$ & Papan Tulis Magnetic & 5 buah \\
\hline
\end{tabular}

\begin{tabular}{|c|c|c|}
\hline $\mathbf{9}$ & Alas duduk & 3 buah \\
\hline $\mathbf{1 0}$ & Kontainer plastik & 2 buah \\
\hline $\mathbf{1 1}$ & Buku Tulis & $\begin{array}{c}5 \text { pak (@ isi } 10 \\
\text { buah })\end{array}$ \\
\hline $\mathbf{1 2}$ & Buku Gambar & 30 buah \\
\hline $\mathbf{1 3}$ & Krayon & 15 pak \\
\hline $\mathbf{1 4}$ & Pensil warna & 10 pak \\
\hline $\mathbf{1 5}$ & Pensil dan penghapus & $@ 5$ kotak \\
\hline
\end{tabular}

\section{KESIMPULAN}

Dari hasil penyelenggaraan kegiatan dapat disimpulkan sebagai berikut :

1. Kegiatan pelatihan mendapat antusiasme yang cukup baik dari peserta. Pelatihan mengenai metode pembelajaran sangat dibutuhkan untuk meningkatkan kualitas pembelajaran di sekolah swasta seperti TK/PAUD Al Fasha. Sebagai sekolah swasta, institusi ini menjalankan kegiatan operasional dengan dana mandiri. Sehingga bantuan dan perhatian dari tim PPM sangat diapresiasi.

2. Pengadaan mainan edukatif, media belajar serta alat tulis bagi TK Al Fasha memiliki dampak yang positif. Pengadaan benda-benda tersebut dapat menambah serta memperbaiki fasilitas yang terdapat di TK Al Fasha. Selain itu benda-benda tersebut dapat memotivasi guru dan siswa untuk semakin giat belajar.

3. Pemberian pelatihan sangat penting bagi guru untuk sekolah inklusi, karena membantu mereka meningkatkan pengetahuan dan keterampilan yang kemudian diterapkan di dalam kelas. Pada akhirnya, peningkatan pengetahuan dan keterampilan tersebut akan meningkatkan kualitas proses belajar mengajar.

\section{SARAN}

Berikut adalah beberapa saran terkait pelaksanaan PPM selanjutnya:

1. Media pembelajaran berupa mainan edukatif dan alat terapi sangat diperlukan. Sehingga jika kegiatan ini berlanjut perlu fokus yang lebih besar untuk meningkatkan fasilitas tersebut.

2. Diperlukan adanya bimbingan yang berkelanjutan bagi guru-guru pengajar. Sehingga pengetahuan dan keterampilan yang telah didapatkan melalui kegiatan PPM ini dapat tetap terasah dan digunakan dengan baik. 
3. Diperlukan partisipasi yang lebih aktif dari pihak sekolah, sehingga dapat mendukung tercapainya tujuan pelaksanaan kegiatan PPM ini.

\section{UCAPAN TERIMA KASIH}

Penulis mengucapkan terima kasih kepada Politeknik Negeri Malang yang telah memberikan dukungan moral dan pendanaan terhadap program pengabdian masyarakat ini.

\section{DAFTAR PUSTAKA}

[1] Kadir, A., 2015, Penyelenggaraan Sekolah Inklusi Di Indonesia, Jurnal Pendidikan Agama Islam, 03, 1-22.

[2] Sopa, A., 2017, Model Penanganan Anak Berkebutuhan Khusus pada Sekolah Inklusif di SDN 54 Kota Banda Aceh.

[3] Undang-undang SISDIKNAS, 2006, Sistem Pendidikan Nasional (p. 6), Sinar Grafika, Jakarta.

[4] Smith, 2006, Inklusi: Sekolah Ramah untuk Semua. Nuansa.

[5] Sunardi, 2003, Pendekatan Inklusif Implikasi Managerial, Jurnal Rehabilitasi Remidias, 3-4.

[6] Yusuf, M., dkk., 2018, Pendidikan Inklusif dan Perlindungan Anak. Metagraf.

[7] Hallahan, D.P., Kauffman, J., 2006, Exceptional Learners: Introduction to Special Education 10th ed (10th (Ed.), Pearson USA.

[8] Yulia, E.T., 2018, Kertas Media Terapi untuk Anak Berkebutuhan Khusus, https://www.qureta. com/post/kertasmedia-terapi-anak berkebutuhan khusus. 